\title{
COMO INSTAURAR PARA SI UMA BUFONA-CIBORGUE-BIXA?
}

\author{
HOW TO ESTABLISH TO YOURSELF A BUFFON-CIBORG-QUEER?
}

Matheus Silva ${ }^{1}$

Resumo: O presente artigo tem o interesse em traçar uma cartografia que visa engendrar os dispositivos teóricos do processo de criação performativa da ação que realizo enquanto performer, "O corpo desembestado de AdivinhaaDiva", que ocupa distintos espaços arquitetônicos explorando as fronteiras entre filosofia e arte da performance. Tal investigação almeja configurar a noção de "corpo desembestado", a partir do cruzamento dos estudos dos conceitos filosóficos de "movimentos aberrantes", de David Lapoujade e "desrazão", de Peter Pál Pelbart, "Inquietude de si", de Cassiano Sydow Quilici; "instauração", comentado por Peter Pál Pelbart e "devir-animal", de Gilles Deleuze e Félix Guattari, para compreender o processo de fazer existir uma "bufona-ciborgue-bixa"; bufona, conforme Joaquim Elias, o ciborgue e a "bixa", de acordo com Donna Haraway, Paul B. Preciado e Paco Vidarte. Trata-se de diagramar os dispositivos teórico-práticos do "corpo desembestado", explanando sobre sua potência de instaurar uma existência "bufona-ciborgue-bixa".

Palavras-chave: Arte da performance; corpo desembestado; bufona-ciborgue-bixa.

Abstract: This present article has the interest of a mapping that craves to engender the theoretical devices of the process of performative creation of the action that I perform, "The body unbridled of AdivinhaaDiva", which occupies different architectural spaces exploring the boundaries between philosophy, art, life and madness. Such an investigation seeks to shape the notion of " unbridled body", according to the intersection of philosophical concepts as "aberrant movements", from David Lapoujade's and Peter Pál Pelbart's "uneasiness", "restlessness of self", by Cassiano Sydow Quilici; "establishment", commented by Peter Pál Pelbart and "becoming-animal" by Gilles Deleuze and Félix Guattari, to understand the process of making a "buffoon-cyborg-bixa"; buffoon, according to Joaquim Elias, the cyborg and the "bixa", according to Donna Haraway, Paul B. Preciado and Paco Vidarte. It is a question of diagramming the theoretical-practical devices of an "unbridled body", explaining its potency to establish a "buffoon-cyborg-queer"

Keywords: Performance art; unbridled body; buffoon-cyborg-queer.

\footnotetext{
${ }^{1}$ Universidade Federal de Minas Gerais, MG, Brasil.
} 


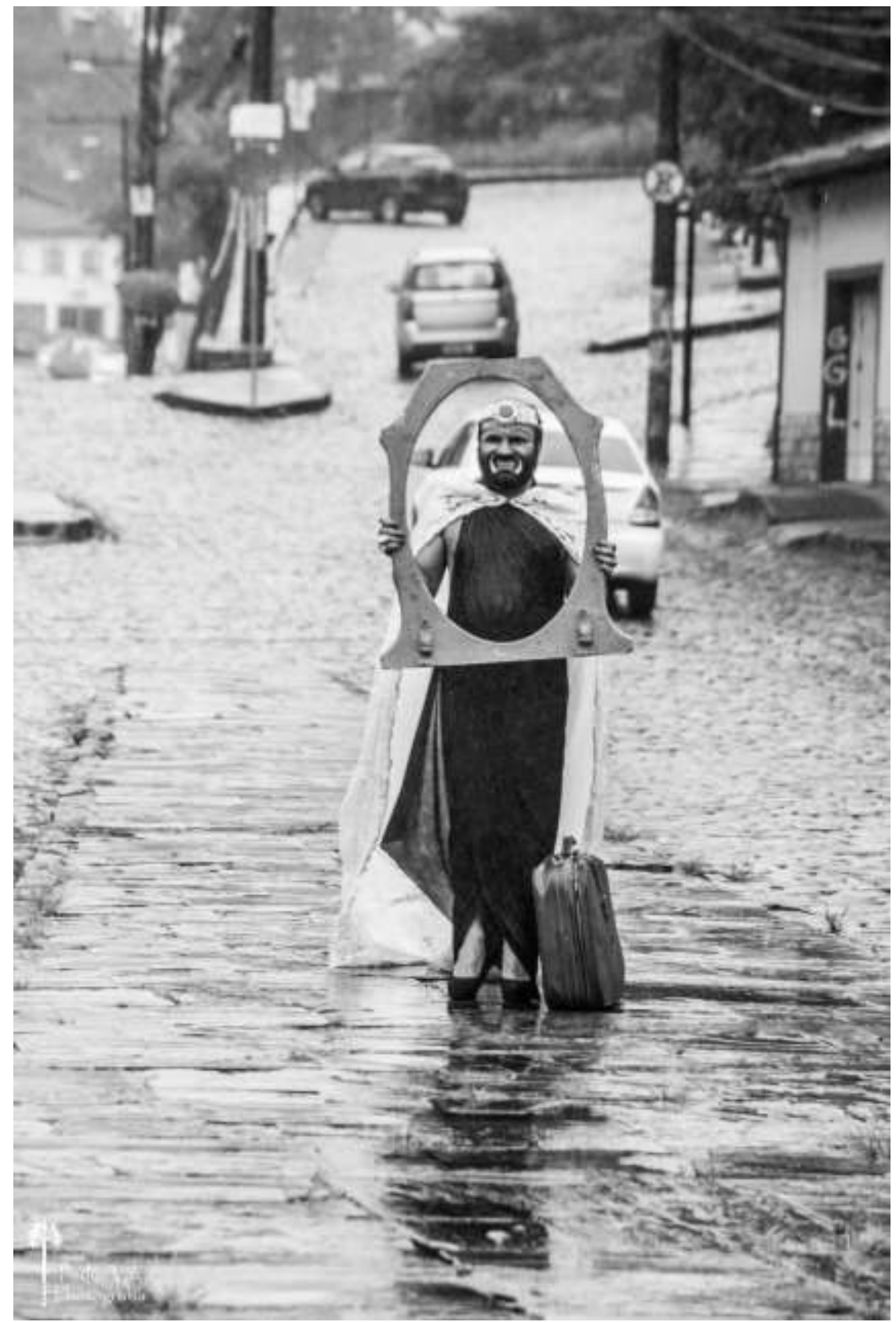

Imagem 1 - "O corpo desembestado de AdivinhaaDiva", durante o evento "Queerlombos: território de guerrilha”, nos arredores da Praça da Estação em Ouro Preto/MG, dia 21 de novembro de 2019.

\subsection{Arte da performance: audácia e prudência}

Para a pesquisadora Jesette Féral (2015), a arte da performance se propõe como um modo de intervenção e de ação sobre o real, em que se foca a gênese de uma visibilidade não representativa, não reconhecível: "O performer instala a ambiguidade de significações, o deslocamento dos códigos, os deslizes de sentido [...] e institui a pluralidade, a ambiguidade [...]" (FÉRAL, 2015, p. 122-123). O performer é, portanto, aquele que testemunha coisas que sem ele não teriam existência e, para estar à altura desse acontecimento, pactua seu corpo com o inusitado, o indizível, o impensado, para assim ousar, permitir, inventar, inovar e correr riscos. 
A aproximação entre a arte da performance com a Live Art torna evidente que, enquanto campo de prática, ambas conseguem ultrapassar os limites de um padrão, apagar as margens entre as disciplinas, amalgamar artista e participador, enfatizar o processo sendo feito, o desenrolar da ação e a experiência que ela traz. Uma realização no qual o performer manipula, explora seu corpo assim como um artista visual faz com uma tela: "é que o performer não representa, ele é. Ele é isso que ele apresenta. Ele é sempre ele próprio, mas em situação. [...] ele é na unicidade da matéria, na imediatidade do fazer, na urgência da experiência" (FÉRAL, 2015, p. 146-147).

Por conceber a presente pesquisa como invenção em arte, faço uso da "cartografia", tal como proposta por Gilles Deleuze e Félix Guattari, como metodologia para a investigação do processo criativo de um "Corpo desembestado". A cartografia enquanto método pensa a partir de elementos que estão tramados entre si, está sempre atenta à travessia de um processo e na natureza rizomática de dar passagens às múltiplas sensações que proliferam e pedem expressão em um dado contexto. Para os autores:

O mapa é aberto, é conectável em todas as suas dimensões, desmontável, reversível, suscetível de receber modificações constantemente. Ele pode ser rasgado, revertido, adaptar-se a montagens de qualquer natureza, ser preparado por um indivíduo, um grupo, uma formação social. Pode-se desenhá-lo uma parede, concebê-lo como obra de arte, construí-lo como ação política ou meditação. [...] Um mapa tem múltiplas entradas contrariamente ao decalque que volta sempre "ao mesmo". Um mapa é uma questão de performance, enquanto que o decalque remete sempre a uma presumida competência (DELEUZE; GUATTARI, 1995, p. 21-22).

Um performer, ao afirmar que sua pesquisa é uma instauração processual de acontecimentos, aprofunda-se no plano da vivência, plano este em que conhecer é produzir uma realidade outra de si e do mundo. Trata-se de produzir novas rotas através da "precariedade", no risco de um corpo que não fica a observar e age; precisa-se partir de uma disposição à uma desnaturalização das leis da normalidade, investir na potência de transformar e dar visibilidade a outros encontros, de recriar e transformar modelos vigentes através de um contínuo movimento de questionar-se e reinventar-se, bem como uma produção cartográfica.

A cartografia não pretende produzir uma cópia da realidade, mas fazer um mapa aberto, modificável, cuja trama implode projeções, símbolos e orientações destinadas a um produto, ou a um ponto de chegada. Não se trata de um processo de descobrimentos, como uma busca por algo que estivesse pronto e encoberto, mas de um conhecimento migratório e processual, inseparável do próprio movimento da vida e seus múltiplos traçados, "afetos, devires, passagens, transposições, campos de territorialização e linhas de desterritorialização" (DELEUZE, 2016, p. 107). Um cartógrafo, assim como um performer, persegue pistas através de um movimento que dão sinais de um percurso, lança suas "frotas" frente ao não vivido, gera novas existências que exploram limiares; transpõe o limiar entre uma "visão e invisão":

Estar no limite, no limiar, é estar no momento preciso em que estamos em parte alguma, mas cá e lá, aqui e ali, no limite que separa onde estamos de onde estávamos e para aonde iremos. [...] Estar no limiar da visibilidade é estar no intervalo que parece nos suspender no espaço e no tempo, nos lançando em uma imensidão. [...] tênue cruzamento como um ponto de reviravolta, de mudança de direção, onde conexões impensáveis tem lugar. Zona de fronteira que revela os

\footnotetext{
${ }^{2}$ De acordo com Lois Keidan, co-fundadora e diretora da Live Art Development Agency "Live Art constitui-se essencialmente de obras artísticas temporárias que cobrem diversas áreas e discursos, envolvendo, de alguma maneira, corpo, espaço e tempo. [...] Live Art é, portanto, o termo para um esquema de modelagem, uma forma de abordagem, acomodação e liberdade de uso de novas formas de trabalho, as quais nem sempre se ajustam às estruturas existentes e às configurações e fronteiras rígidas das áreas reconhecidas de expressão artística". Disponível em: http://www.forumpermanente.org/revista/edicao-0/textos/liveart (acesso em 16 de maio de 2021).
} 
limites da nossa visão e o que deles escapa, acentuando que a configuração da trama do visível é efêmera, instável [...]. O que vemos se desenha, se estrutura e se transforma a cada fusão de imagens (DIAS, 2010, p. 216-217).

Assim, é possível pensar a arte da performance enquanto um espaço limiar entre múltiplas disciplinas e agregados sensíveis, como artes visuais, dança, música, literatura, filosofia, poesia, teatro. Esse limiar se interessa pelas franjas e bordas das disciplinas, o que torna a arte da performance uma espécie de fusão artística que se dá enquanto desvio, deslocamento, enquanto um elemento de desarticulação de discursos unívocos, hierárquicos e sedimentados e subverte a própria ação enquanto acontecimento, no decorrer do seu processo inventivo.

Uma exploração perpassada pela radicalidade de uma vivência, "um acontecimento que eclode da transgressão programada de convenções estéticas e sociais, apostando na eficácia transformadora (política, estética, existencial, etc.) de suas estratégias" (QUILICI, 2015, p. 107). O perfomer passa a enfocar mais o processo, nas rearticulações de um corpo atento à travessia, aos movimentos entre o pesquisador e o pesquisado, ao curso subjetivo e objetivo, à maneira "rizomática" 3 e processual da produção de conhecimentos, funções e variações. Tratase, enfim, de uma prática de acoplagens acidentais, cuja dinâmica extrapola completamente qualquer dado inicial, reverberando variações inusitadas. Uma arte de viver, que se constitui em novos modos de existência e outras possibilidades de vida. Tudo é passagem e travessia, e estamos desde sempre e para sempre inseridos ali, em ação:

Não há bem dizer surpresa, apenas uma espera mais ou menos longa, curiosa, e a questão: "O que ele está fazendo? Porque ele está fazendo isso? O que ele quer dizer? Até quando ele poderá ir? Quanto tempo poderá ficar nisso? E depois a interrogação angustiada "Porque estou aí? Quanto tempo minha paciência vai aguentar? O que há aí realmente para se ver? (FÉRAL, 2015, p. 141).

\subsection{Pistas filosóficas para uma instauração anômala}

Um corpo na arte da performance atua pela "transbordância", pelo câmbio, pela simbiose, escapa constantemente a uma organização e produz a partir das forças que o assaltam, gera uma nova potência, um movimento "auto-expressivo" do sensível. De fato, um corpo "esgotado" que atravessa a semelhança, deforma semblantes, desfigura imagens através de um procedimento que consiste em fazê-las proliferar e conceber outras sempre singulares e performáticas, sem ordem hierárquica, espacial ou cronológica. Uma “desrazão” e, para Pelbart (2009, p. 155):

o hiato entre desrazão e loucura foi se diluindo ao longo do tempo, desaguando numa coincidência à qual ainda estamos submetidos. Se a desrazão foi "capturada" pela loucura, não é de surpreender que a única forma de manifestação da desrazão seja a loucura, uma loucura que será, então, marcada pelo índice do grito, da vigília e da desforra. A desrazão "enclausurada" não pode "romper o cerco" a não ser pela exacerbação e violência. A loucura será a máscara já colada ao rosto da qual a desrazão quer livrar-se, o que só é possível desfigurando-a, no exagero das caretas e dos clamores. Usar a máscara para arrebentá-la, assim como é preciso desfigurar as palavras para deixar aparecer os sons.

\footnotetext{
${ }^{3}$ BAREMBLITT, 2010, p. 35. "Um rizoma, ou seja, um sistema transsistêmico, uma espécie de rede móvel de canais, fluxos, redemoinhos e turbulências, de limites internos e externos difusos."
} 
A loucura é aqui investigada a partir de um aprofundamento dos conceitos de "movimentos aberrantes" e "desrazão", que viriam contribuir à elaborar um conceito produtivo e de um outro lugar de percepção desse termo: "Quanto mais irracional, mas aberrante -e, portanto, mais lógico" (LAPOUJADE, 2015, p. 13). Uma polifonia de sensações abertas e críticas, de "marcas involuntárias, livres, irracionais, acidentais, insignificantes e assignificantes, confusas, feitas à mão com uma esponja, trapo, escova" (PELBART, 2009, p. 94), como penso ser necessário para um processo de criação artística de um performer inquieto e desassossegado. Uma inquietude que, como afirma Quilici (2015, p. 138-139):

[...] não designa a falta de nada específico, uma inquietude sem objeto, ligada mais à intuição de que nada no mundo pode aplacar nossa "fome do absoluto" (Antonin Artaud), nosso "desejo infinito" (Emmanuel Levinas). Penso aqui na arte que não é feita para esconder esse desassossego vital, mas que ajuda a reconhecê-lo, penetrá-lo e transformá-lo. [...] A "inquietude de si” surgiria de uma apreensão mais clara da temporalidade da existência, da instabilidade dos fenômenos, da insegurança fundamental que permeia nosso estar no mundo, e ela nos desafia a encontrar outros encaminhamentos para as nossas energias, outros modos de lidar com as tensões do estar vivo.

Um "corpo desembestado" passaria, então, por uma afecção de borda que rompe o cerco com a razão. Esta "desrazão" é a pura capacidade de agir, de "esgotar" a pretensão de uma individualidade, de uma subjetividade estanque. A potência produtiva da arte da performance é justamente desabituar, "desprogramar" o corpo para evidenciar a mutabilidade e vulnerabilidade do vivo e da vivência. Para isto, é preciso desmanchar o "eu" cristalizado para que outras forças ganhem corpo, para que então os "devires" possam se atualizar e promover horizontes perceptivos inesperados. Trata-se da capacidade de um corpo em dar saltos intensivos, atravessar fronteiras, abrir passagens e liberar a vida das individualidades estanques que a aprisiona, seja nos gêneros, nas espécies ou nos reinos apartados. "Devir é alucinar, delirar e fabular. Mas num outro sentido, delírios e fabulações são reais - no sentido em que novos corpos e as novas linguagens que produzem são pelo menos tão reais quanto a realidade preexistente que contestam" (LAPOUJADE, 2015, p. 281). É nessa atividade intensiva que o corpo se potencializa e convoca suas regiões estrangeiras:

Tudo no animal é metamorfose, e a metamorfose está em um mesmo circuito devir-homem do animal e devir-animal do homem. [...] o devir-animal é uma viagem imóvel e no mesmo lugar, que só pode se viver e compreender em intensidade (transpor limiares de intensidade). O devir-animal não tem nada de metafórico. Nenhum simbolismo, nenhuma alegoria. Não é tampouco o resultado de uma falha ou de uma maldição, o efeito de uma culpa [...]. É um mapa de intensidades. É um conjunto de estados, todos distintos uns dos outros, enxertados sobre o homem enquanto ele busca uma saída. É uma linha de fuga criadora que não quer outra coisa que não a si mesma [...]. O devir animal não deixa subsistir nada da dualidade de um sujeito de enunciação e de um sujeito de enunciado, mas constitui um só e mesmo processo [...] (DELEUZE; GUATTARI, 2014, p. 68-69).

Através deste procedimento intensivo, os autores destacam uma "operância" das matilhas, que se arrastam para longe de si mesmas, são prolongadas para além da subjetividade até uma vizinhança que lhes permite uma transmutação amplificada. Matilha enquanto relação com o 
"fora" , um agenciamento que desloca comodismos habituais, rompe binarismos e fornece uma relação nômade, fluida e interrompida. Corpos cuja dinâmica extrapola os territórios, oferecendo um campo de metamorfose, de mutação, de passagens "fluxionárias" que desfazem tudo aquilo que hierarquiza e é fundador:

Em suma, todo Animal tem seu Anômalo. Entendamos: todo animal tomado em sua matilha ou sua multiplicidade tem seu anômalo. Pôde-se observar que a palavra "anômalo" [...], substantivo grego que perdeu seu adjetivo, designa o desigual, o rugoso, a aspereza, a ponta de desterritorialização [...]. O anômalo não é nem indivíduo nem espécie, ele abriga apenas afectos, não comporta sentimentos familiares ou subjetivados, nem características específicas ou significativas. Tanto as ternuras quanto as classificações humanas lhe são estrangeiras [...]. Nem indivíduo, nem espécie, o que é o anômalo? É um fenômeno, mas um fenômeno de borda. Eis nossa hipótese: uma multiplicidade se define, não pelos elementos que a compõem em extensão, nem pelas características que a compõem em compreensão, mas pelas linhas e dimensões que ela comporta em "intensão" (DELEUZE; GUATTARI, 1997, p. 23-24-25).

Atualizam-se corpos anômalos e aberrantes que não são imprecisos nem gerais, mas imprevistos, demoníacos ou excessivos. Isso porque, conforme Lapoujade (2015, p. 11-13), "tais movimentos aberrantes não têm nada de arbitrário; são anomalias só de um ponto de vista exterior. [...] os movimentos aberrantes constituem a mais alta potência de existir, enquanto que as lógicas irracionais constituem a mais alta potência de pensar". Trata-se de atingir um limiar de sensações puras no qual as formas e significações humanas perdem sua "pregnância", indo ao encontro de suas "matilhas" e bandos selvagens. Uma "anomalia" capaz de ligar-se e "instaurar" $n$ arranjos.

Tal instauração, via arte da performance, abre fendas de autonomia no próprio corpo e oferece suporte à um ser de sensação, um trânsito livre para existências. Advoga pela possibilidade de algo existir problematizando o espetáculo social em que estamos imersos. É um corpo que instaura uma coexistência mínima e "precária" que possibilita um incessante deslizamento de nossas apreensões e ações no mundo: "Instaurar consiste em fixar a existência de um ser, assim como estabelecemos uma instituição, uma cerimônia ou um ritual. Criar é instituir ou formalizar. E formalizar é fazer passar para a existência a arquitetura envolvida no ser virtual, ainda no estado "implexo" (LAPOUJADE, 2017, p. 81). Um corpo desembestado é um híbrido feito de conjunções tendentes às deformidades necessárias e capazes de gerarem:

modos de existência singulares, humanos e não humanos. Que tipo de existência se lhes pode atribuir, a esses "seres" que povoam nosso cosmo, agentes, actantes, sujeitos larvares, entidades com suas maneiras próprias de se transformarem e de nos transformarem? Nem objetivo nem subjetivo, nem reais nem irreais, nem racionais nem irracionais, nem matérias nem simbólicos, seres um tanto virtuais, um tanto invisíveis, metamórficos, moventes, a que categoria pertencem? E em que medida existem por si mesmos? Quanto dependem de nós? Quanto estão em nós? [...] Alguns deles têm o duplo traço de nos transformarem em outra coisa, mas também de por

\footnotetext{
${ }^{4}$ PELBART, 2009, p. 87- 88. Sobre o fora: "Relação com o estranho, o estrangeiro, a alteridade, com aquilo que irremediavelmente estará fora, do meu tempo, da minha consciência, do meu eu, da minha palavra, do meu controle. Estará fora do meu mundo, de forma desconhecida, impessoal, na mais próxima distância, na mais ausente das presenças, como aquilo que excede o meu pensar, convulsiona o meu sentir, desarma meu agir."
} 
sua vez se transformarem em outra coisa. Que faríamos sem eles? Seríamos sempre eternamente os mesmos (PELBART, 2016, p. 392).

Assim, um corpo desembestado é aquele "cuja existência se legitima por si mesma "por uma espécie de demonstração radiante de um direito à existência, que se afirma e se confirma pelo brilho objetivo, pela extrema realidade de um ser instaurado" (PELBART, 2016, p. 393). Trata-se de um corpo capaz de reconectar-se a percepções infinitesimais que instauram novas existências. É assim que apreendo a "instauração" no corpo desembestado: uma co-produção que se efetua não como uma estrutura, instância, nem sensorial, nem metafísico, mas um modo maquínico de abrir passagens, acolher, deixar vir à tona e fazer correr energias, frequências e ressonâncias autônomas. Coloca-se aberto ao risco indeterminado para corroborar e defender o direito à legitimidade desses povos nômades que perambulam por ele, já que ele "almeja algo como uma Arte de instaurar, ou Arte de fazer existir seres que ainda vagam na penumbra, ficcional, virtual, longínqua, enigmática" (PELBART, 2016, p. 393-394), na medida que proclama, nesse limiar de visibilidade, outras possibilidades mais sensíveis de viver:

Uma certa "arte de existir", de "instaurar a existência". Para que um ser, coisa, pessoa ou obra conquiste existência - e não apenas exista -, é preciso que ele seja instaurado. A instauração não é um ato solene, cerimonial, institucional, como quer a linguagem comum, mas um processo que "eleva" o existente a um patamar de realidade e esplendor próprios - patuidade, diziam os medievais. Instaurar significa menos criar pela primeira vez do que estabelecer "espiritualmente" uma coisa, garantir-lhe uma "realidade" em seu gênero próprio (PELBART, 2016, p. 393).

\subsection{Instaurar uma bufona-ciborgue-bixa}

Como superar a atrofia dos sentidos, promover a instauração dessas existências "esgotadas" e contagiantes? Apreendo a produção de um corpo desembestado como uma dissolução da tradição, em prol de vidas "de outra ordem", mais desarrazoada, menos centrada nos polos das noções nas quais habitualmente dispomos. Pude apreender como a bufonaria compartilha uma concepção sensível e convulsiva de arte-vida, engajando o corpo em um processo radical de reconstrução de mim e do mundo, bem como um bufão.

Podemos considerar os bufões como agentes de subversão dos valores
instituídos, atuando como uma espécie de contraponto da norma
predominante. Eles podem provocar a transgressão da ordem e dos tabus, seja
através do riso, da zombaria ou do jogo da inversão. A começar pela forma
como se apresentam, eles nos chamam a atenção para o excesso, atraindo para
si o olhar acostumado e causando certa inquietação com sua presença.
Geralmente se manifestam feios ou deformados, grosseiros e mal educados,
mas podem também revelar-se através de uma beleza diabólica ou sedutora,
de maneira que sua aparência seja um convite à sua admiração. O fato é que
nunca se deixam alcançar totalmente, sempre escapando pelo lado oposto
àquele pelo qual tentamos capturá-los (ELIAS, 2018, p. 38).

Os bufões permitem revoluções nos corpos cercados pela indústria de culturas hegemônicas, triunfantes e, em sua existência, tocam a dimensão singular do desconhecido, do "precário", do fulero, do provisório. Tal corpo, assim, deve esgotar-se do que o aprisiona, bem como da inscrição dos poderes diversos sobre o mesmo, ou mesmo a sua redução a uma intensa 
"docilização" e domesticação adquiridas. Provocam o nascimento de uma força desestabilizadora das formas vigentes para instaurarem novas combinações, na qual promovemse diferenças de estado sensível em relação aos estados já conhecidos e situáveis:

Eles precisam surgir de lugares longínquos, trazendo mensagens importantes, porém ocultas, e para serem apreendidas necessitam de certo tipo de envolvimento que ultrapassa a mera compreensão intelectual. A fala do bufão ecoa algo profundo e enigmático que está além da realidade objetiva. Em certo sentido, parece-me quando o bufão surge em cena, melhor dizendo, quando um ator empresta seu corpo para o bufão atuar, o que ele nos revela é um pouco da alma mesma dos artistas em busca constante por outras formas de perceber as coisas, de se relacionar com o mundo, de rir de si mesmo e do absurdo da vida, enfim, de sua habilidade de ir além da vida ordinária (ELIAS, 2018, p. 112).

Bem como um bufão, "O ciborgue pula o estágio da unidade original, sua identificação com a natureza, no sentido ocidental [...] O ciborgue está determinadamente comprometido com a parcialidade, a ironia, a perversidade" (HARAWAY, 2013, p. 39). As energias intercambiáveis entre os campos "bufão-ciborgue" possuem uma natureza adicional, não buscam a justa forma; anseiam por mais conectividade. Como funciona essa conjunção, essa confluência em distintos espaços? Em que medida, em um processo de criação artística, desembestar-se, disparar-se, soltarse, perder-se o freio? Trata-se, por fim, de um processo que é acompanhado por pistas e sinais desconhecidos, e não por certezas, fundamentos e pertinências pré-existentes.

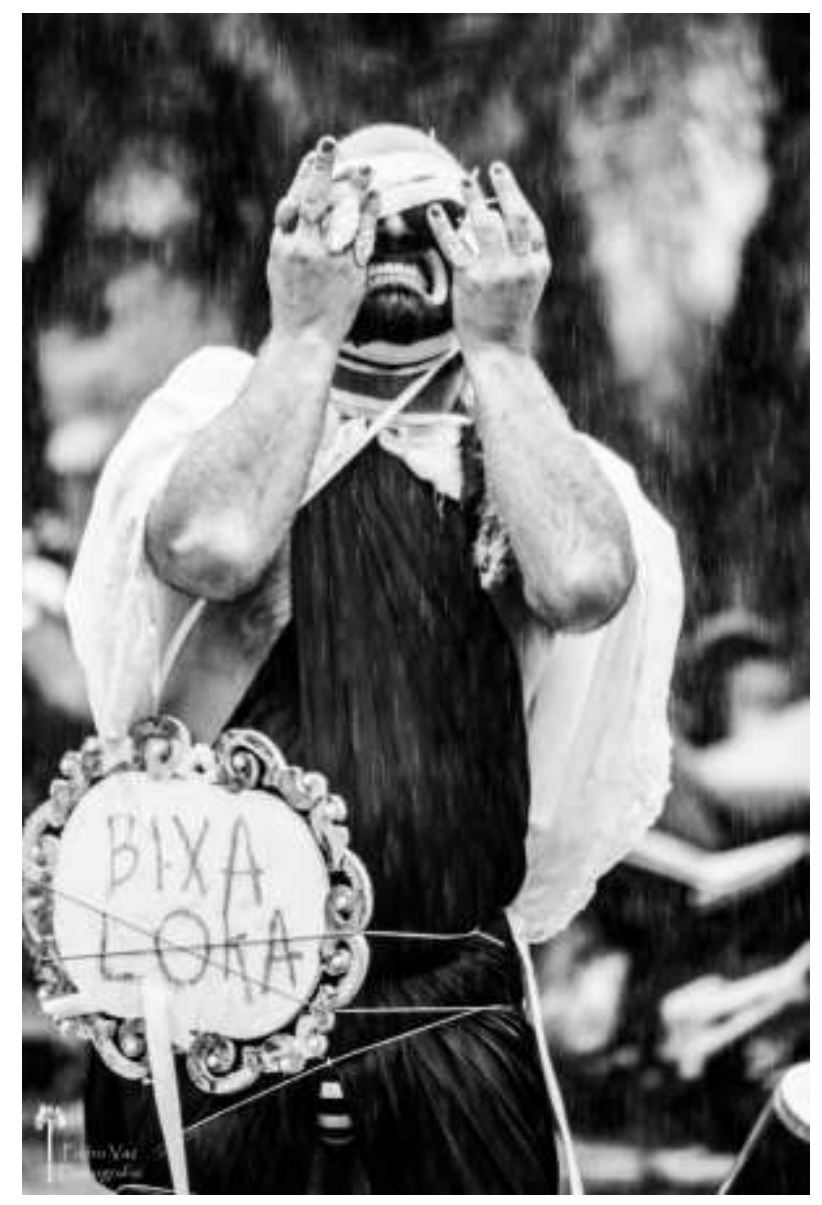

Imagens 2 - "O corpo desembestado de AdivinhaaDiva", durante o evento "Queerlombos: território de guerrilha", nos arredores da Praça da Estação em Ouro Preto/MG, dia 21 de novembro de 2019. 
O ciborgue não é um sistema matemático e mecânico fechado, mas um sistema aberto, biológico e comunicante. O ciborgue não é um computador, e sim um ser vivo conectado a redes visuais e hipertextuais [...]. A questão não reside em escolher entre robôs e os ciborgues. Já somos ciborgues que incorporam próteses cibernéticas e robóticas. Não há volta. [...] as bio e cibertecnologias contemporâneas são, ao mesmo tempo, o resultado das estruturas de poder e os possíveis bolsões de resistência a esse mesmo poder; de uma forma ou outra, um espaço de reinvenção da natureza (PRECIADO, 2014, p. 167-168).

Conforme Haraway (2013, p. 41), o "ciborgue aparece como mito precisamente onde a fronteira entre o humano e o animal é transgredida [...]. Os ciborgues assinalam um perturbador e prazerosamente estreito acoplamento entre eles". Atualiza-se por alteração contínua e novas articulações improváveis; é um ser "monstruoso", na medida em que se desacorrenta de constrangimentos, dogmas, servidões e qualquer fundamentação estacionária. Realiza tal operação, uma vez que pensa o processo de transmutar-se em "um mundo sem gênero, que será talvez um mundo sem gênese, mas, também, um mundo sem fim. A encarnação ciborguiana está fora da história da salvação. Ela tampouco obedece a um calendário edípico (HARAWAY, 2013, p. 38). É uma afirmação de si vital concretizada sob um corpo que convoca esses seres que vagam na sua órbita:

Paul Beatriz Preciado chega a afirmar que a teoria queer é pós-identitária. Tratase de colocar uma posição crítica frente às normas heterocentradas, atendendo-se também para a normatização e a exclusão que acontece até mesmo dentro do seio da cultura gay, lésbica etc. É nesse contexto que a expansão do termo "queer" se torna necessária. Já existe uma variedade de invisíveis sociais, e é por isso que começamos essa lição: não levando em conta os grupos citados, mas sim, abordando um tema importante da filosofia que é a distinção entre natureza e cultura, levando em conta dentro desta distinção os animais não humanos, pensando que o animal é ainda tão queer quanto tantos humanos que não tem a sua representatividade, os seus direitos básicos e ainda sofrem violência extrema. $O$ animal é queer (LEOPOLDO, 2017, p. 16).

Devir "bixa", em um corpo desembestado, passa a ser um movimento de descolar-se das constrições subjetivas pré-estabelecidas, essa forma humana assujeitada que visa servir a um CIS-tema heteropatriarcal encerrado e autoritário, ao mesmo tempo em que devém perceptível suas verdadeiras transfigurações, emancipando-se de um poder que o marginaliza. Uma existência aberrante bufona-ciborgue-bixa é instaurada, percorrida por forças inumanas e animalescas que resistem à essas normas heterocentradas, desfazendo e boicotando o ambiente cultural em que elas se propagam. Tal animalidade, em nós, dada a sua natureza anômala, sempre estranha à sua própria expressão, aumenta a coesão das forças de composição e de vida, emancipando novos arranjos e alterando distintos elementos: "O ser, ou os seres, são apenas e tão somente engrenagens da vida. [...] eis que chegamos ao animal em nós, mas também em nós no animal que somos. Somos todos os animais e nenhum, tanto que eles também são outros em seus devires contínuos (SCHÖPKE, 2016, p. 296). Sua extrema fúria preza pela liberdade em sua vida, e a arranca de onde ela está encarcerada, "equilibrada" e estabilizada em um conforto que a paralisa. Trata-se de um regime inventado para um exercício de direito à vida bixa e monstra, sem nada que a constranja ou a limite, bem como de instauração de ações de aferro às normas ou, então, à normatização de tudo.

\footnotetext{
${ }^{5}$ BAREMBLITT, 2010, p. 33. “Aqui, 'monstruoso' deve-se entender de acordo com o que Deleuze aprendeu de seu mestre Canguilhem, ou seja, como o anômalo, aquilo que está nos limites, ou até mais além de sua própria espécie.”
} 
Como lidar com aqueles que defendem que é possível questionar a homossexualidade baseado em convicções religiosas, alegando direito à liberdade de expressão? É preciso acentuar que o nome disso não é fé, é opressão, e fazer da "bufona-ciborgue-bixa" uma turbina de engendramentos políticos e existenciais, como fissura e provocação estratégica, cujo interesse é preservar as forças de prevenção da vida, "despertando novas sensibilidades e atitudes, outras formas de fazer política e da gente se comprometer solidariamente na luta contra a homofobia e os homofóbicos" (VIDARTE, 2019, p. 09).

Uma ética bixa deve nascer justamente da singularidade de pertencimento a uma coletividade, neste caso, partindo de mim como bixa, um indivíduo particularmente bixa (como cada leitor será outro), que pretende comunicar um modo de vida, de ação, de comportamento, de sociabilidade, de inscreverse no contexto concreto de um país com o intuito de que suas propostas possam ser compartilhadas e entrar em sintonia com as de outros membros da comunidade gay, sem a qual ele sequer pode se pensar como indivíduo. Basta com que sejam alguns. Uma ética bixa sempre será particular, pois nossa particularidade de ser bixa vem antes de qualquer outra coisa. Todas as éticas universalistas, feitas para todo mundo, acabam nos massacrando, nos discriminando, nos prejudicando. Quando alguém fala em nome de uma ética universal, uma ética para a humanidade, pode ter certeza que será contra nós. Por isso, minha pretensão é restrita, uma ética para nós, para uns poucos gays e lésbicas, inclusive contra gays e lésbicas. Assim, é particular, singular. [...] Uma ética bixa deveria recuperar a solidariedade entre os oprimidos, discriminados e perseguidos, evitando estar a serviço de éticas neoliberais criptorreligiosas herdadas em que fomos criados e nos quais se forjaram nossos interesses de classe, e recuperar a solidariedade com outros que foram e são igualmente oprimidos, discriminados e perseguidos por razões diferentes de sua opção sexual. (VIDARTE, 2019, p. 22).

Corpo cujas "máquinas de guerra" inventam novos modos de vida ativa capazes de promover, de acordo com Preciado (2014, p. 10), "opções de resistência à norma: não essencializantes, menos excludentes, atentas aos efeitos totalizadores da norma e articuladas mais a partir das noções de diferença ou margem do que identidade" para atingir o seu ilimitado campo de imanência. Está-se cartografando um espaço vida, um mapa "irrastreável" que "rompe com toda uma série de binômios oposicionistas: homossexualidade/heterossexualidade, homem/mulher, masculino/feminino, natureza/tecnologia [...]" (PRECIADO, 2014, p. 11). Este é o desafio do performer: fazer a vida fugir em todos os sentidos e direções, "não é permanecer homem ou mulher, é extrair de seu sexo as partículas, as velocidades e lentidões, os fluxos, os $n$ sexos [...]" (DELEUZE; GUATTARI, 1997, p. 70).

Porque instaurar-se "bufona-ciborgue-bixa"? Por que instaurar a AdivinhaaDiva? "Só nos tornamos reais ao tornar mais reais outras existências" (LAPOUJADE, 2017, p. 95). É preciso aberrar contra tudo que quer nos punir, castigar, seja através de um gesto de desprezo e indiferença, seja com sua total fúria psicológica excludente, seja pela violência física sobre nossos corpos. Um corpo desembestado está em constante exercício de uma apoteose bixa, uma exuberância bufônica, da qual toda uma "montação" ciborgue monstruosa gera uma revolução existencial, alarga ainda mais os campos de possibilidades de vida. Funciona, portanto, não de modo atributivo, mas conjuntivo, por alternâncias e entrelaçamentos, semelhanças e diferenças, atrações e distrações, arrebatamentos e nuanças, por proposições abertas ao contato, à escuta, à convivência, à divergência, à convergência, à resistência e à aderência. 


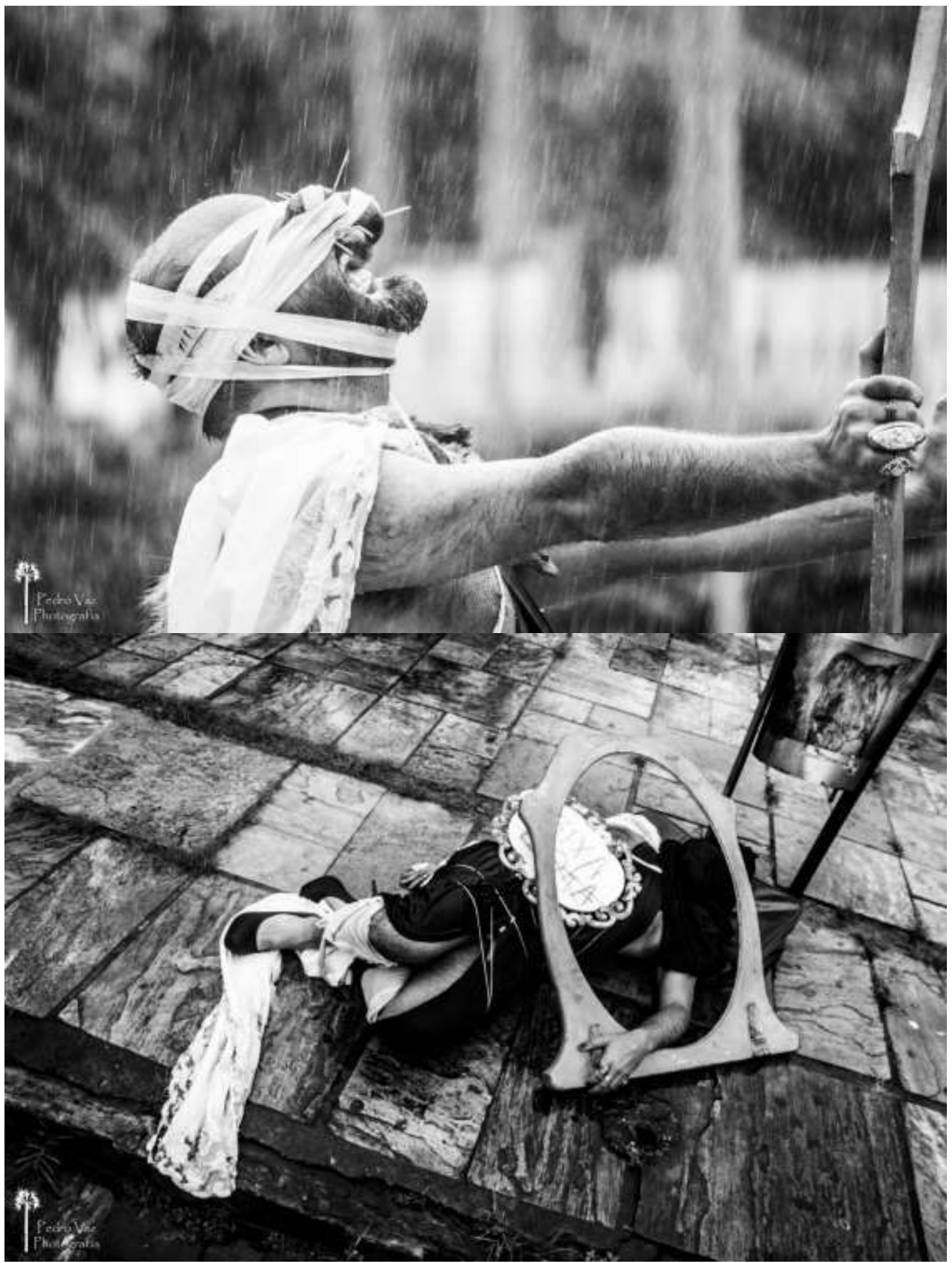

Imagens 3 e 4 - "O corpo desembestado de AdivinhaaDiva", durante o evento "Queerlombos: território de guerrilha”, nos arredores da Praça da Estação em Ouro Preto/MG, dia 21 de novembro de 2019.

\section{Referências}

BAREMBLITT, Gregório F. Introdução à esquizoanálise. Belo Horizonte: Biblioteca da Fundação Gregório Baremblitt/Instituto Félix Guattari, 2010. 
DELEUZE, Gilles. Dois regimes de loucos: textos e entrevistas. Edição preparada por David Lapoujade. Tradução de Guilherme Ivo. Revisão técnica de Luiz B. L. Orlandi. São Paulo: Editora 34, 2016.

DELEUZE, Gilles; GUATTARI, Félix. Kafka: por uma literatura menor. Tradução de Cintia Vieira da Silva; revisão da tradução de Luiz B. L. Orlandi. Belo Horizonte: Autêntica Editora, 2014.

DELEUZE, Gilles; GUATTARI, Félix. Mil platôs: capitalismo e esquizofrenia. v. 1. Tradução de Aurélio Guerra Neto e Celia Pinto Costa. São Paulo: Editora 34, 1995.

DELEUZE, Gilles; GUATTARI, Félix. Mil platôs: capitalismo e esquizofrenia. v. 4. Tradução de Suely Rolnik. São Paulo: Editora 34, 1997.

DIAS, Karina. Entre Visão e Invisão: Paisagem (Por uma experiência da paisagem no cotidiano). Brasília: Ed. UNB, 2010.

ELIAS, Joaquim. No encalço dos bufões. Belo Horizonte: Javali, 2018.

FÉRAL, Josette. Além dos limites: teoria e prática do teatro. Tradução de J. Guinsburg. São Paulo: Perspectiva. 2015.

HARAWAY, Donna J. "Manifesto ciborgue: ciência, tecnologia e feminismo-socialista no final do século XX.” In: HARAWAY, Donna; KUNZRU Hari. Antropologia do ciborgue: as vertigens do pós-humano. Organização e tradução de Tomaz Tadeu. Belo Horizonte: Autêntica Editora, 2013.

LAPOUJADE, David. As existências mínimas. Tradução de Hortencia Santos Lencastre. São Paulo: n-1 edições, 2017.

LAPOUJADE, David. Deleuze, os movimentos aberrantes. Tradução de Laymert Garcia dos Santos. São Paulo: n-1 edições. 2015.

LEOPOLDO, Rafael. Teoria Queer \& Micropolítica: questões para o ensino médio. Rio de Janeiro: Editora Multifoco, 2017.

PELBART, Peter Pál. Da clausura do fora ao fora da clausura: loucura e desrazão. São Paulo: Iluminuras, 2009.

PELBART, Peter Pál. O avesso do niilismo: cartografias do esgotamento. São Paulo: n-1 edições, 2016.

PRECIADO, B. Paul. Manifesto contrassexual - Práticas subversivas de identidade sexual. Tradução de Maria Paula Gurgel Ribeiro. São Paulo: n-1 edições, 2014.

QUILICI, Cassiano Sydow. O ator-performer e as poéticas da transformação de si. São Paulo: Annablume. 2015. 
SCHÖPKE, Regina. “O vitalismo libertário de Gilles Deleuze. Anti-humanismo e etologia dos afetos: a animalidade restituída. In: OLIVEIRA, Jelson (Org.). Filosofia animal: humano, animal, animalidade. Curitiba: PUCPRess, 2016.

VIDARTE, Paco. Ética bixa: proclamações libertárias para uma militância LGBTQ. Tradução de Maria Selenir dos Santos e Pablo Cardellino Soto. São Paulo: n-1 edições, 2019.

\section{Sobre o autor}

Matheus Silva. Doutorando em Artes da Cena pelo Programa de Pós-Graduação em Artes da Universidade Federal de Minas Gerais (UFMG). Bolsista CAPES.

E-mail: matheus_silva84@yahoo.com.br. 